\title{
CONTRA EL CONFORMISMO
}

\author{
LUIS EDUARDO BRESCIANI L. \\ Director, Escuela de Arquitectura, \\ Pontificia Universidad Católica de Chile
}

$\mathrm{N}$ os enfrentamos a tiempos de abruptos cambios sociales, culturales y económicos, donde muchas de las convicciones de antaño pierden sentido y la incertidumbre domina los contextos institucionales que antes delimitaban nuestras prácticas arquitectónicas. Ante este panorama, en lugar de repensar los nuevos marcos conceptuales que definen las fronteras de la arquitectura, nos vemos expuestos a un exacerbado dominio de la cultura del mercado y la competencia, que promueve visiones individuales y autorreferentes por sobre cualquier intento de proyecto colectivo.

No se trata de negar las fuerzas globales que dominan el contexto de la práctica de la arquitectura contemporánea, pues la arquitectura siempre ha sido una expresión de los tiempos y las sociedades que la habitan. Pero es evidente que la creciente dependencia del capital nos empuja hacia la estandarización de los programas y la diferenciación basada en estilos y apariencias, haciendo aún más difícil la condición reflexiva y de transformación inherente a todo proyecto de arquitectura, paisaje y ciudad.

Esta tensión obliga a superar la mera - y muchas veces banal - difusión de imágenes, proyectos y obras para privilegiar el debate cultural e ideológico, incluso político, referido a las fuerzas y contextos que afectan el diseño de nuestro medio construido, generando nuevos espacios de compromiso, diálogo y reflexión crítica, renegando de todo conformismo.

\section{Contra la certidumbre}

Subsiste en nuestra cultura el anhelo del control monopólico de la práctica de la arquitectura, ya sea a manos del Estado, los gremios o las instituciones académicas. Para algunos, estas serían las claves que asegurarían la influencia de los arquitectos en la transformación del medio construido y en las agendas políticas y culturales. Sin embargo, parece obvio que este deseo responde más a miedos e incertidumbre ante los efectos de los cambios en el contexto global sobre lo que hoy entendemos por producción arquitectónica.

Esta incertidumbre, en lugar de alimentar la búsqueda de nuevas respuestas y la expansión intelectual del debate arquitectónico, puede traducirse en el refugio de la cultura profesional en la educación universitaria formal, en convenciones históricas o demandas de protección legal, sin reconocer que históricamente la relación entre arquitectura y sociedad se ha reproducido mediante la construcción de códigos culturales y visiones ideológicas respecto del rol del diseño del proyecto de arquitectura.

Por eso, las cualidades que definen nuestra profesión u oficio no pueden reducirse a un conjunto de conocimientos, prácticas y habilidades, sino que remiten a la capacidad de construir y difundir visiones ideológicas y estrategias políticas sobre el rol de la arquitectura en la construcción de la ciudad y el paisaje contemporáneo. Son las ideas y discursos detrás de las obras e investigaciones las que llevan a ampliar los 
límites de la arquitectura o, en el peor de los casos, a provocar su encierro e intrascendencia. De aquí la importancia del desafío curatorial y el sentido de publicaciones de arquitectura como revista $A R Q$.

\section{Contra la autocomplacencia}

¿Cómo influir efectivamente en la arquitectura de las ciudades y el paisajes? Esta pregunta pone a la arquitectura en el espacio del poder y la política en el sentido más amplio. Impone la urgencia de entrar en la arena del debate ideológico sobre la arquitectura - sobre los valores, las prioridades y los beneficiarios de la arquitectura. Ello implica reconocer que las transformaciones del espacio construido no surgen completamente de la práctica disciplinar, sino de fuerzas económicas, sociales y culturales, lo que debiera alimentar una mayor comprensión de la sociedad contemporánea a la cual sirve la arquitectura y una mejor relación con otras disciplinas, cuestionando nuestra autocomplacencia y autorreferencia.

Incluso hablar de 'disciplina' como un campo de acción delimitado y autónomo es discutible. Como sostiene Mohsen Mostafavi, «el propio término 'disciplina', con sus connotaciones explícitas de autoridad y orden, es incompatible con los valores contemporáneos de apertura y diversidad» (Mostafavi, 20I2), lo que obligaría a atreverse a cuestionar los límites convencionales de la arquitectura, evitando marginar las múltiples dimensiones y expresiones de la misma.
Sólo cabe resistirse a la idea de que ampliar el debate arquitectónico a los grandes temas de nuestro tiempo nos podría distanciar del oficio del proyecto. Por el contrario, la necesidad de permanente ajuste y sintonía con los nuevos contextos globales obliga a tensionar y someter a crítica permanente lo que hacemos.

En este contexto, la creación y publicación de conocimiento y posiciones valóricas para influir en el diseño del medio construido, haciendo explícitos los discursos y principios ideológicos que están detrás del diseño en todas sus escalas, conectan a la arquitectura con los grandes debates sociales, políticos y culturales de nuestro tiempo. Ese es el rol de las revistas y publicaciones sobre arquitectura. No nos distraen, nos vuelven al centro, nos hacen conscientes y mejoran la capacidad de influir con lo que diseñamos e investigamos.

\section{Bilbiografía}

mostafav1, Mohsen. «Matter of Discipline», Harvard Design

Magazine 35 (2012). 